\title{
Expression of a prokaryotic P-type ATPase in E. coli Plasma Membranes and Purification by $\mathrm{Ni}^{2+}$-affinity chromatography
}

\author{
Markus Geisler ${ }^{*}$
}

Institut für Biochemie der Pflanzen, Heinrich-Heine-Universität Düsseldorf, D-40225 Düsseldorf, Germany.

* Present address: The Royal Veterinary and Agricultural University, Department of Plant Biology, Plant Physiology/Anatomy Laboratory, Thorvaldsensvej 40, DK-1871 Frederiksberg C, Denmark. E-mail: mag@ staff.kvl.dk

\begin{abstract}
In order to characterize the P-type ATPase from Synechocystis 6803 [Geisler (1993) et al. J. Mol. Biol. 234, 1284] and to facilitate its purification, we expressed an N-terminal 6xHis-tagged version of the ATPase in an ATPase deficient $E$. coli strain. The expressed ATPase was immunodetected as a dominant band of about $97 \mathrm{kDa}$ localized to the $E$. coli plasma membranes representing about $20-25 \%$ of the membrane protein. The purification of the Synechocystis 6xHis-ATPase by single-step Ni-affinity chromatography under native and denaturating conditions is described. ATPase activity and the formation of phosphointermediates verify the full function of the enzyme: the ATPase is inhibited by vanadate $\left(\mathrm{IC}_{50}=119 \mu \mathrm{M}\right)$ and the formation of phosphorylated enzyme intermediates shown by acidic PAGE depends on calcium, indicating that the Synechocystis P-ATPase functions as a calcium pump.
\end{abstract}

\section{ABBREVIATIONS}

EP, phosphoenzyme; IPTG, isopropyl- $\beta$-D-thiogalactopyrano-side; Ni-NTA, $\mathrm{Ni}^{2+}$-nitrilotriacetic acid; PM, plasma membrane; PMCA, plasma membrane $\mathrm{Ca}^{2+}$-ATPase(s); SER, sarco(endo)plasmic reticulum; SERCA, sarco(endo)plasmic reticulum $\mathrm{Ca}^{2+}$-ATPase(s), 6xHis, 6 x histidine affinity tag.

\section{INTRODUCTION}

The Synechocystis PCC 6803 P-ATPase (sll1614 (13)) belongs to the superfamily of P-type ATPases catalyzing the transport of various cations (1) and aminophospholipids (2). All the members contain one large subunit with several highly conserved domains related to ATP-binding, phosphorylation and ATPhydrolysis. During their reaction cycle, a high energy aspartyl-phosphate intermediate (EP) appears (16), further, all of them exhibit sensitivity toward vanadate.

Structurally, the Synechocystis P-ATPase described in (12) belongs to the subfamily of eukaryotic $\mathrm{Ca}^{2+}-$

(C)1998 Biological Procedures Online. All rights reserved. Paper-based copying permitted for internal use for educational or non-profit purposes only. Otherwise, this article may be copied to paper provided that \$US15 per copy is paid directly to Biological Procedures Online, GMO 106 Box 44, Waterloo ON, Canada N2L 3G1. Electronic copying, storage or redistribution prohibited. ISSN: 1480-9222 
ATPases of the SER-type (12). These SERCA (16-18) differ from the Ca-ATPases of the PM-type (1921 ) in a number of biochemical and functional properties. The ATPase is most similar to the Synechococcus $7942 \mathrm{Ca}^{2+}$-ATPase (5). Further, the enzyme has been shown to be cotranscribed with a GTPase gene located downstream from the ATPase gene (15).

Kinetic and immunological investigations of cytoplasmic membranes from Synechocystis 6803 have shown that this P-type ATPase is present in very small amounts. Further, the investigation of this enzyme is limited by the existence of nine P-ATPase genes revealed during the analysis of the entire genome of Synechocystis 6803 (13). Beside the one described here, three more putative $\mathrm{Ca}^{2+}$-ATPase genes were identified. The other five ATPase genes resemble typical prokaryotic P-ATPases; two of them show striking homologies to cadmium pumps, and one to the $k d p B$ subunit of the E. coli potassium pump (14).

Therefore, we developed a heterologous expression system of the 6xHis-tagged Synechocystis ATPase in $E$. coli to prove the assumed calcium specificity of this P-ATPase. The purification of the engineered enzyme under native conditions by $\mathrm{Ni}^{2+}$-affinity chromatography (11) after detergent solubilization is described. This method has been proven efficient for a number of soluble proteins but has not been used routinely for membrane-embedded proteins. The expressed enzyme is active both in the delipidated and the membrane-bound form as shown by phosphoenzyme formation and ATPase activity. In the original article (3) special emphasis is laid on functional differences to eukaryotic $\mathrm{Ca}^{2+}$-ATPases. Differing from this, we describe here how despite its toxicity in prokaryotic systems, E. coli can alternatively be used as a suitable host for the heterologous expression of members of this superfamily.

\section{MATERIALS AND METHODS}

Oligopeptide Synthesis and Antiserum Production - Rabbits were immunized s.c. with $500 \mu \mathrm{g}$ of a 15-mer oligopeptide (amino acid residues 651-664 of the Synechocystis enzyme (12)) coupled to keyhole limpet hemocyanin in an equal volume of Freund's complete adjuvans (Difco Labs., Detroit). Injections were repeated after 3 weeks in Freund's incomplete adjuvans and monovalent antisera were purified by caprylic acid and ammonium sulfate precipitation.

Expression of the Synechocystis 6803 P-ATPase in E. coli - E. coli strains TKR2000 (14) and M15 (Qiagen) carrying the repressor plasmid pREP4 (Qiagen) were transformed with the engineered plasmid pQE32-8 constructed as described elsewhere (3). The first 5 aa of the native enzyme (MDFPT) were, substituted by the sequence MRGSHHHHHHGIRMRARYP. Large-scale expression cultures (400 or $800 \mathrm{ml} \mathrm{SB}$ (SB: $25 \mathrm{~g}$ bacto-tryptone, $15 \mathrm{~g}$ yeast extract, $10 \mathrm{~g} \mathrm{KCl}$ per liter)) supplemented with $2 \%$ glucose $(\mathrm{w} / \mathrm{v})$, ampicillin $(200 \mu \mathrm{g} / \mathrm{ml})$ and kanamycin $(25 \mu \mathrm{g} / \mathrm{ml})$ were inocculated 1:50 with mid-log precultures. At a cell density of $0.4(550 \mathrm{~nm}), 10 \mu \mathrm{M}$ IPTG was added; after $3-4 \mathrm{~h}$, cells were harvested by centrifugation, washed with washing buffer (1 mM EDTA, $50 \mathrm{mM}$ Tris/Cl pH 8.0) and stored frozen.

Purification of the expressed Synechocystis 6xHis-ATPase - Cells were resuspended in glycerolbuffer ( $5 \mathrm{ml} / \mathrm{g}$ wet weight; $300 \mathrm{mM} \mathrm{NaCl}, 30 \%$ (v/v) glycerol, $1 \mathrm{mM} \beta$-mercaptoethanol, $10 \mathrm{mM}$ Tris/Cl $\mathrm{pH}$ 8.0), and $n$-octylglucoside (46 mM) or TX-100 (1\%) was added. After freezing in $\mathrm{N}_{2}$ and thawing 
on ice, cells were sonicated and the expressed 6xHis-ATPase was solubilized by stirring for $1 \mathrm{~h}$ at $0^{\circ} \mathrm{C}$. After addition of Ni-NTA agarose (5 ml/g wet weight; Qiagen) and 2-5h agitation, the resin was packed into a column. For analytical chromatography, the column was washed with glycerol buffer containing 0 - $40 \mathrm{mM}$ imidazole and $4.6 \mathrm{mM} n$-octylglucoside until the $\mathrm{A}_{280}$ of the flow-through was less than 0.01. The 6xHis-ATPase was eluted by a FPLC-mediated 0 - $500 \mathrm{mM}$ imidazole gradient containing $0.46 \mathrm{mM}$ $n$-octylglucoside. For preparative chromatographies, a third washing step with $60 \mathrm{mM}$ imidazole was added and the protein was eluted by $5-10 \mathrm{ml}$ of glycerol buffer containing $250 \mathrm{mM}$ imidazole.

Slot-Blot and Western Blot Analysis - Aliquots of collected fractions from the Ni-chelate affinity chromatography were vacuum blotted onto nitrocellulose using the slot-blot system from Schleicher \& Schuell. Total cell extracts, recombinant plasma membranes from E. coli TKR2000/pQE32-8 and purified Synechocystis 6xHis-ATPase were separated by 7.5\% PAGE of the Laemmli-type (24), electroblotted to nitrocellulose and immunodetected using the Amersham ECL system.

Phosphorylated intermediates of the Synechocystis $\mathbf{C a}^{2+}$ - ATPase - Phosphoenzyme formation was performed in $50 \mu \mathrm{l}$ of ice-cold medium containing $20 \mathrm{mM}$ MOPS, $\mathrm{pH} 7.0,80 \mathrm{mM} \mathrm{KCl}, 5 \mathrm{mM} \mathrm{MgCl}_{2}$ with $\left[\gamma^{32} \mathrm{P}\right]$ ATP and the specified supplements for $20 \mathrm{~s}$. Purified Synechocystis $6 \mathrm{xHis}$-ATPase $(2 \mu \mathrm{g}$ protein) was added and after $10 \mathrm{~min}$ phosphorylation was terminated by the addition of $0.5 \mathrm{ml} 10 \%$ TCA. After $15 \mathrm{~min}$ at $0^{\circ} \mathrm{C}$, the pellets were washed once with ice-cold distilled water. For SDS-gel electrophoreses, samples were resuspended in $10 \mu \mathrm{l}$ of Papp loading buffer (23) for 10 min at room temperature using a Hamilton syringe. Phosphorylated membranes were separated by $7.5 \%$ PAGE of the Laemmli-type (24); phosphorylated intermediates of the purified 6xHis-ATPase were run on acidic 7.5\% SDS-polyacryamide gels of the Sarkadi-type (18) at $4^{\circ} \mathrm{C}$. Gels were Coomassie stained, dried and autoradiographed.

ATP hydrolysis assays - ATPase activity of the membrane-bound (plasma membrane vesicles from $E$. coli TKR2000/pQE32-8 (30 - $100 \mu \mathrm{g}$ of protein)) or purified 6xHis-ATPase (2 - $7.5 \mu \mathrm{g}$ of protein) was measured at $37^{\circ} \mathrm{C}$ in a volume of $1 \mathrm{ml}$. After preincubation for $10 \mathrm{~min}$ in hydrolysis buffer $(50 \mathrm{mM} \mathrm{KCl}$, $50 \mathrm{mM} \mathrm{MgCl}_{2}, 50 \mathrm{mM} \mathrm{HEPES} / \mathrm{KOH} \mathrm{pH7.5)} \mathrm{with} \mathrm{the} \mathrm{specified} \mathrm{supplements} \mathrm{the} \mathrm{reaction} \mathrm{was} \mathrm{started} \mathrm{by}$ the addition of $2 \mathrm{mM}$ ATP including $\left[\gamma^{32} \mathrm{P}\right]$ ATP. Aliquots of $300 \mu 1$ were drawn after 5,10 and $15 \mathrm{~min}$, stopped with $1 \mathrm{M} \mathrm{HClO}_{4}$ on ice and radioactivity of inorganic phosphate was measured by liquid scintillation counting. Plasma membrane vesicles from E. coli TKR2000/pQE32 (without ATPase insert) show ATP hydrolysis rates in the same order as the blank values (no enzyme addition); the experimental data were corrected by these blank values.

\section{RESULTS AND DISCUSSION}

Expression of the Synechocystis 6xHis-ATPase - Membrane proteins overexpressed in E. coli can be toxic for the host cells (25), most likely due to the association of the protein with or incorporation into vital membrane systems (26). To control expression strictly, we used the expression vector pQE32 in combination with the repressor plasmid pREP4 (Qiagen). The expression vector contains two lac operator elements which permits in combination with high levels of lac repressor provided from the pREP4 plasmid, some control over the expression on the transcriptional level. For cloning, E. coli XL1 Blue (Stratagene)-harboring the $l a q^{q}$ mutation and therefore producing enough lac repressor-was 
suitable. But this strain was less efficient for expression most probably due to its leaky transcription before induction. For the production of higher yields and subsequent purification, the strain M15[pREP4] (Qiagen) was used.

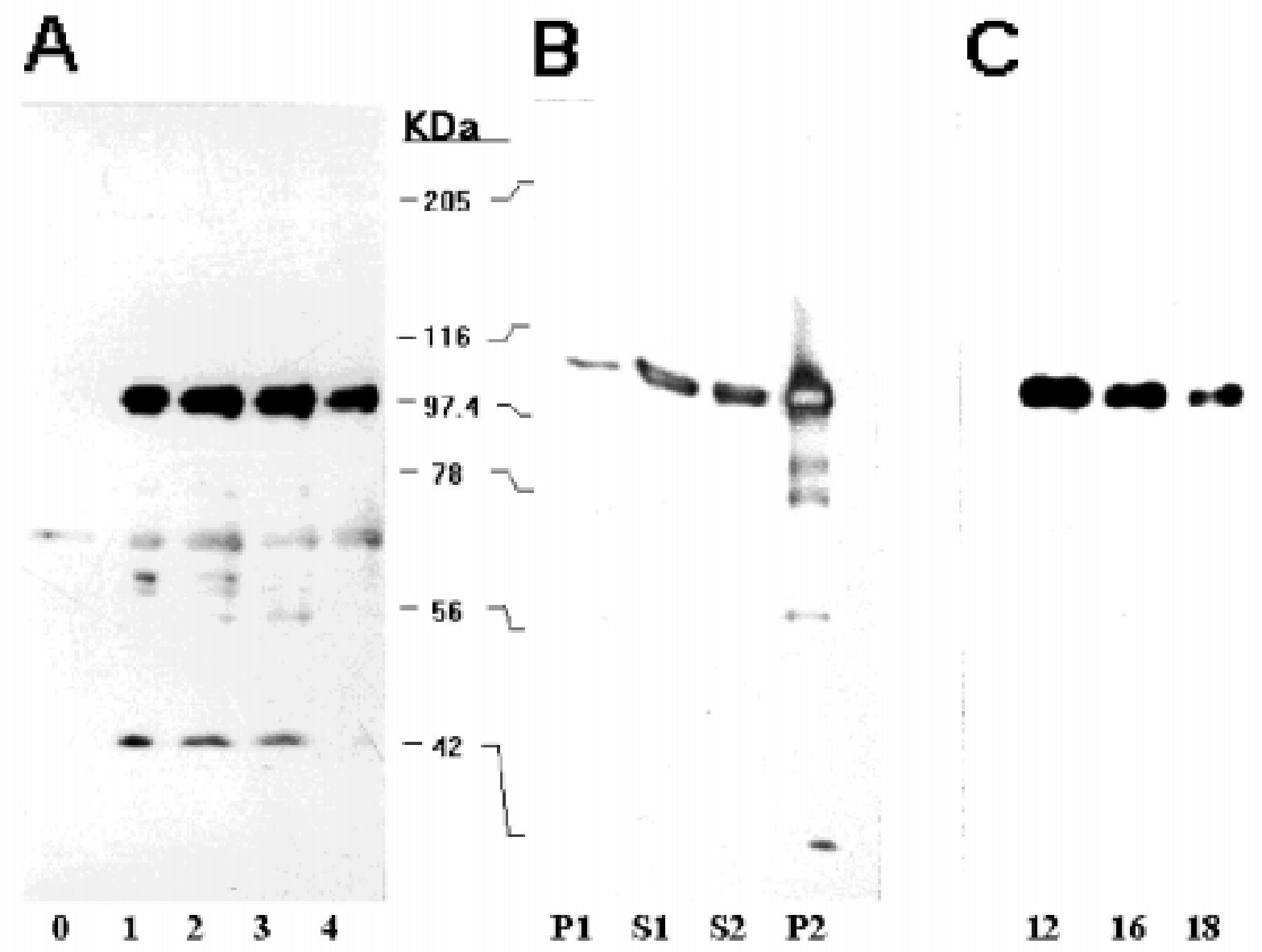

Fig. 1: Expression of the Synechocystis 6xHis-ATPase in E. coli. (A) E. coli TKR2000/pQE32-8 was grown in SB medium, and total cell extracts were taken before (lane 0) and 1,2,3 and 4h (lane 1 - 4) after induction with $10 \mu \mathrm{M}$ IPTG. (B) Cells were harvested after $3 \mathrm{~h}$, lysed by sonication and cellular debris was removed by centrifugation at $10.000 \mathrm{xg}$ (P1). The supernatant (S1) was centrifuged at $100.000 \mathrm{xg}$ and the pellet was resuspended and washed by centrifugation as before (supernatant $=\mathrm{S} 2$, pellet $=\mathrm{P} 2$ ). (C) Aliquots of fractions 12, 16 and 18 obtained from an analytical FPLC-mediated purification (see Fig. 2) were taken for separation. All samples were subjected to 7.5\% PAGE, blotted onto nitrocellulose and immunostained with antisera raised against the synthesized peptide.

Further, it became obvious that for reasonable expression levels, freshly transformed cells, mid-log precultures, and high levels of ampicillin $(200 \mu \mathrm{g} / \mathrm{ml})$ were essential to maintain construct stability. Highest production of heterologous protein was obtained using the rich SB medium supplemented with $2 \%$ glucose to maximize repression of expression and early inductions at an $\mathrm{A}_{550}$ of 0.4 . Various IPTG concentrations were tested; mild induction of $E$. coli M15/pQE32-8 using $10 \mu \mathrm{M}$ concentrations of IPTG leading to only partial clearing of the promoter turned out to be a good compromise between toxicity and reasonable expression yields. 
The Synechocystis P-ATPase was immunodetected as a dominant band of about $97 \mathrm{kDa}$ by immunoblotting of total cell extracts from TKR2000/pQE32-8 cells (Fig. 1A lane 1). Most of the recombinant ATPase was found in the membrane fractions (Fig. 1B, lane P2) while only small amounts were found to be soluble (lane S1 and S2). Using the genetically engineered strain E. coli TKR2000 (14) lacking the ATPase activities of both the plasma membrane-bound $\mathrm{K}^{+}$-ATPase of the P-type $(\Delta$ $k d p A B C D E 81(9))$ and the F-ATPase $(\triangle I B E F H A)$ we were able to use recombinant plasma membranes directly for the investigation of the membrane-bound enzyme (see ATP hydrolysis assay). The yield of total plasma membrane protein obtained was up to $5 \mathrm{mg}$ from $1 \mathrm{~g}$ (wet weight) of cells. Immunological quantitation using isolated 6xHis-ATPase as a standard revealed that the content of the Synechocystis ATPase on the total plasma membrane protein was between 20 and $25 \%$.

Purification of the Synechocystis 6xHis-ATPase by Ni-affinity Chromatography - After solubilization of plasma membrane proteins of transformed E. coli by non-ionic detergents, the 6xHistagged ATPase was purified by Ni-chelate affinity chromatography (11). Beside TX-100 used under denaturating conditions, $n$-octylglucoside turned out to be more efficient than dodecyl-maltoside or Tween-20. To avoid elution of contaminating proteins due to disulfide cross-linkages, hydrophobic or ionic interactions, $1 \mathrm{mM} \beta$-mercaptoethanol, $30 \%$ glycerol and $300 \mathrm{mM} \mathrm{NaCl}$ were added. Binding in a batch procedure and subsequent packing of the resin-protein complex into a column seemed to be much more efficient compared to the column procedure. To receive higher yields, the binding time was elongated up to $4 \mathrm{~h}$. 
In analytical preparations, most of the 6xHis-ATPase is eluted between 70 and $200 \mathrm{mM}$ by a linear 0 500 mM FPLC-mediated purification imidazole gradient (see Fig.2). For large-scale preparations, a step gradient was applied with a third extensive washing step containing $60 \mathrm{mM}$ imidazole and an elution step with $250 \mathrm{mM}$ imidazole yielding in $300 \mu \mathrm{g}$ of highly purified ATPase protein (from $1 \mathrm{~g}$ (wet weight) of cells).

Under denaturating conditions (8 M Urea/ 1\% TX-100) the yield was three-fold higher due to a more efficient solubilization and binding of the 6xHis-ATPase to the affinity matrix. Efficient purification of the engineered ATPase under native and denaturative conditions show that the N-terminal His-tag of the ATPase is exposed and easy accessible for the Ni-NTA agarose.

\section{Phosphoenzyme formation of the} Synechocystis 6xHis-ATPase - To investigate whether the expressed

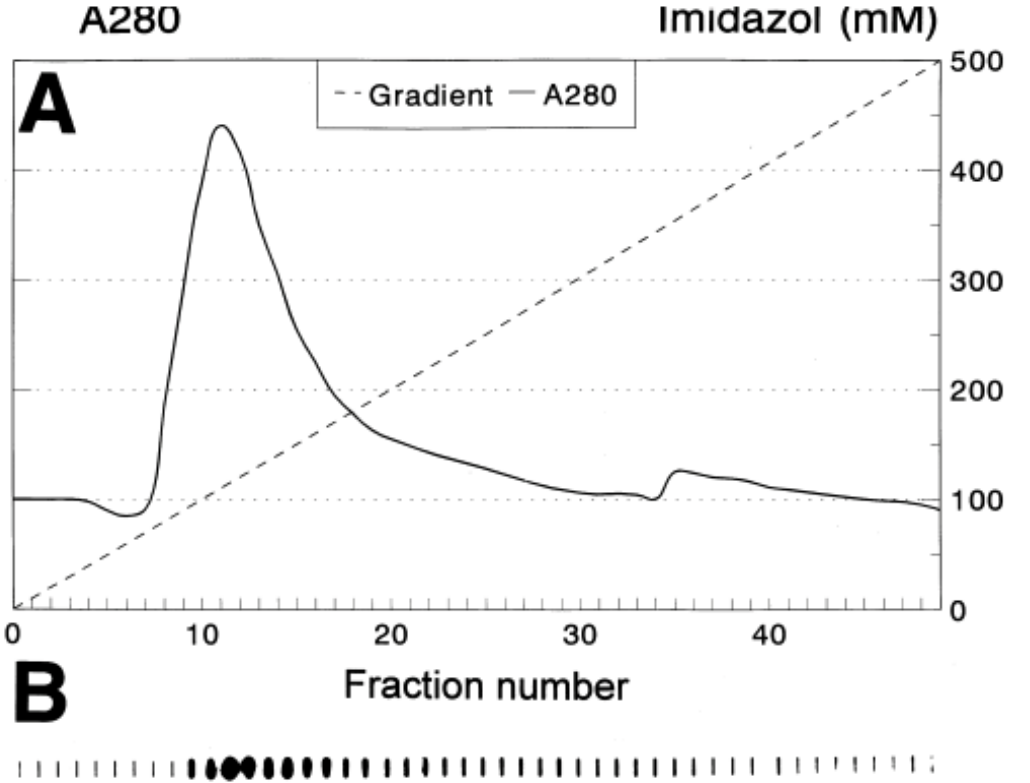

Fig. 2: Ni-chelate affinity chromatography of the expressed Synechocystis 6xHis-ATPase. Sonicated cells were treated with $46 \mathrm{mM} n$ octylglucoside and bound to Ni-NTA agarose by stirring at $0^{\circ} \mathrm{C}$ for $3 \mathrm{~h}$. The agarose was washed with glycerol buffer containing 0,20 and $40 \mathrm{mM}$ imidazole in the batch, packed into the column and eluted by a linear FPLCmediated gradient $(0-500 \mathrm{mM}$ imidazole containing $0.46 \mathrm{mM} n$ octylglucoside). Elution was detected at $\mathrm{A}_{280}$ (A) and aliquots of each fractions were immunodetected by slot-blot analysis (B).

enzyme is active, the isolated enzyme was exposed to $\left[\gamma^{32} \mathrm{P}\right]$-ATP under different conditions in order to form phosphorylated enzyme intermediates $\left(\mathrm{E}_{1} \mathrm{P}(16)\right)$. For phospho-intermediate separation, LiDSPAGE at pH 2.4 (6), acidic SDS-PAGE of the Sarkadi-type (18) and PAGE of the Laemmli-type (24) were tested. While LiDS-PAGE resulted in only limited separation, acidic SDS-PAGE at an actual pH of 5.5-7 (18) resembled a good compromise between separation and conservation of the acyl-phosphate linkage. However, Laemmli gels at an actual $\mathrm{pH}$ of 9.5 (18) can also be used to separate phoshorylated intermediates; loss of radiolabelling could be compensated by longer exposition times. 
In the presence of $\left[\gamma^{32} \mathrm{P}\right] \mathrm{ATP}$, the ATPase forms a $97 \mathrm{kDa}$ phosphointermediate (Fig. 3, lane 1) which is strongly calcium dependent: chelation of calcium by EGTA (5 mM) reduces phosphorylation strongly (Fig. 3, lane 2) supporting the assumption that the enzyme acts as a $\mathrm{Ca}^{2+}$-ATPase in vivo. The phosphointermediate is highly sensitive to higher temperatures and to hydroxylamine (see Fig. 2B in the original article) indicating an acylphosphate linkage.

Furthermore, $\mathrm{E}_{1} \mathrm{P}$ formation is strongly enhanced by addition of the dephosphorylation blocking $\mathrm{La}^{3+}$ (Fig. 3, lane 3) increasing the steady state concentration of phosphorylated intermediate (18). The stabilization by lanthanum has been described so far only for mammalian PM Ca ${ }^{2+}$-ATPases (18) and the SERCA3 isoform of rat kidney (23).

ATP hydrolysis by the Synechocystis 6xHis-ATPase Determination of ATPase activity showed that the isolated as well as the membrane-bound Synechocystis 6xHis-ATPase is active. In the presence of calcium, the ATPase activity of membrane vesicles show a linear rate of $3.16 \tilde{\mathrm{n}} 0.30 \mu \mathrm{mol} / \mathrm{h} \times \mathrm{mg}$ of protein; the rates of the isolated enzyme are about ten times higher. Considering an inside-out orientation of membrane-vesicles of about $50 \%$ and an ATPase proportion of $20-25 \%$ on total membrane protein, the ATPase activities of isolated and of membrane-bound enzymes are therefore equivalent. $\mathrm{pH}$ and temperature dependencies of the Synechocystis ATPase activity show broad optima (Fig. 4) with an alkaline $\mathrm{pH}$ optimum as reported for the SERCA3 isoform (10).

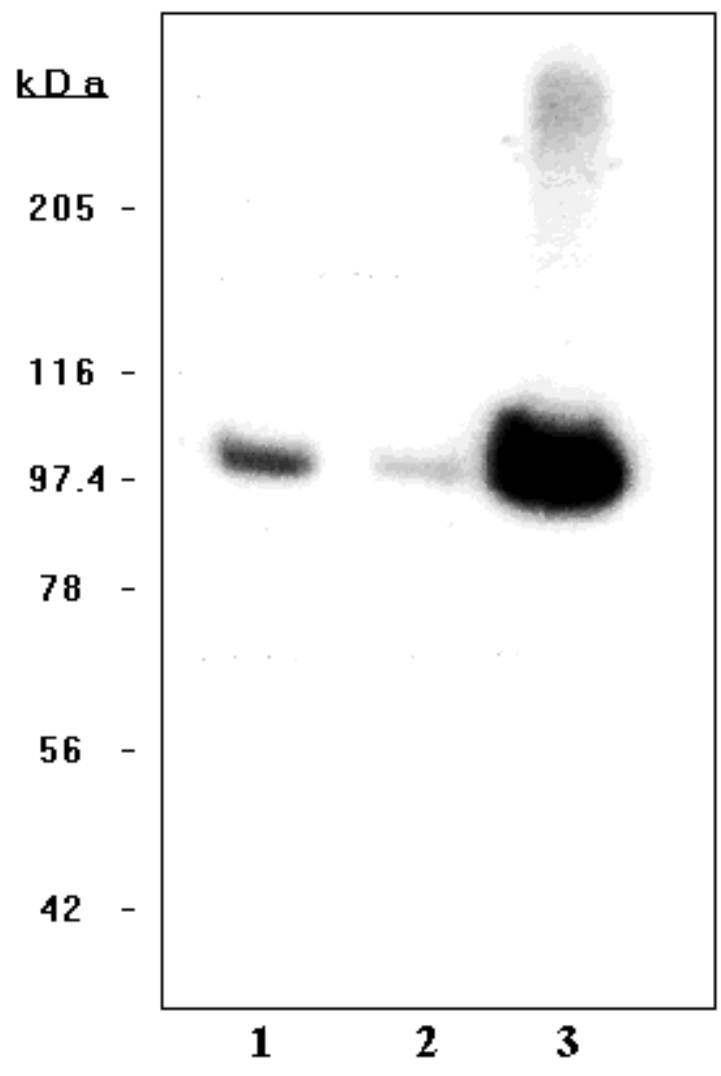

Fig. 3: Phosphorylated intermediates of the purified Synechocystis 6xHis-ATPase. $2 \mu \mathrm{g}$ of the isolated enzyme expressed in E. coli and purified by $\mathrm{Ni}$-chelate chromatography were incubated with $\left[\gamma^{32} \mathrm{P}\right] \mathrm{ATP}$ in $\mathrm{MOPS} / \mathrm{KCl} / \mathrm{MgCl}_{2} / 500 \mu \mathrm{M} \mathrm{C \textrm {Ca } ^ { 2 + }}$ medium (lane 1) supplemented with either $5 \mathrm{mM}$

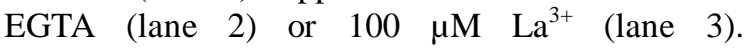
Phosphorylated intermediates of the isolated were separated on $7.5 \%$ PAGE of the Sarkadi-type as described under Materials and Methods. 

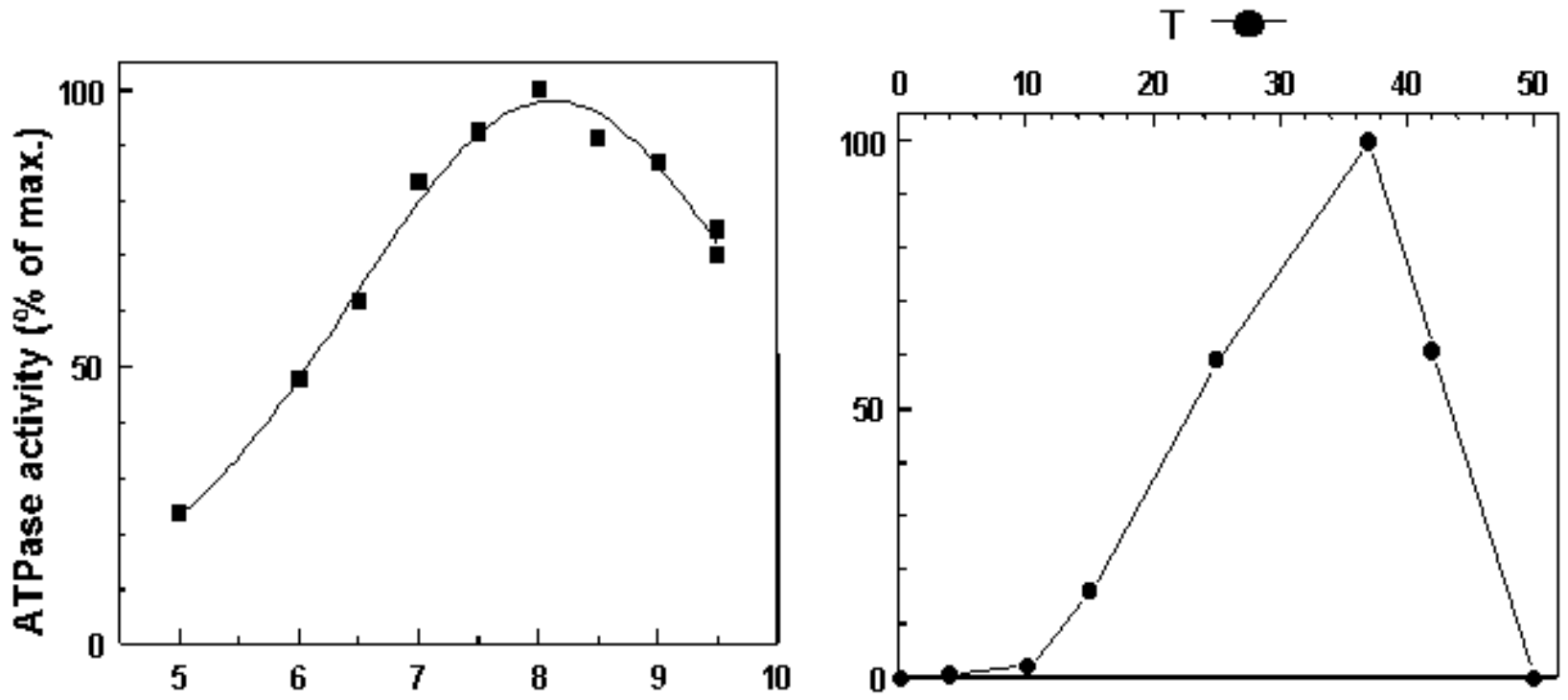

Fig. 4: pH and temperature dependence of ATPase activity of the expressed Synechocystis 6xHis-ATPase. ATPase activity of recombinant plasma membranes from E. coli TKR2000/pQE32-8 (50 $\mu \mathrm{g}$ protein) was assayed at $37^{\circ} \mathrm{C}$ at various $\mathrm{pH}$ values $(\mathrm{p})$. Temperature dependent ATP hydrolysis $(\bullet)$ was determined at $\mathrm{pH} 7.5$ using $2 \mu \mathrm{g}$ of isolated enzyme in hydrolysis buffer plus $100 \mu \mathrm{M} \mathrm{Ca}^{2+}$. Rates are calculated in percent of the maximum activity.

Both preparations showed only a calcium stimulation of ATPase activity between $10 \%$ and $20 \%$ while a strong $\mathrm{Ca}^{2+}$-stimulation was found in the EP formation experiments (Fig. 3). On the other hand, addition of the calcium ionophor A23187 to recombinant membrane vesicles resulted in a $15 \%$ stimulation of ATP hydrolysis indicating a more stringent calcium dependence of the membrane-bound enzyme. Similar results have been reported for a microsomal $\mathrm{Ca}^{2+}$-ATPase of yeast (8) and for the ER-localized $\mathrm{Ca}^{2+}$ ATPase of carrot cells (7). So far, we have no indications for a negative effect of the N-terminal 6xHis tag on the folding and activity of the enzyme in respect to its calcium specificity. The physiological role of the hydrophilic N-terminal stretch is unknown, however, a negative effect caused by the insertion of the 6 histidine residues is unlikely but cannot be excluded. 


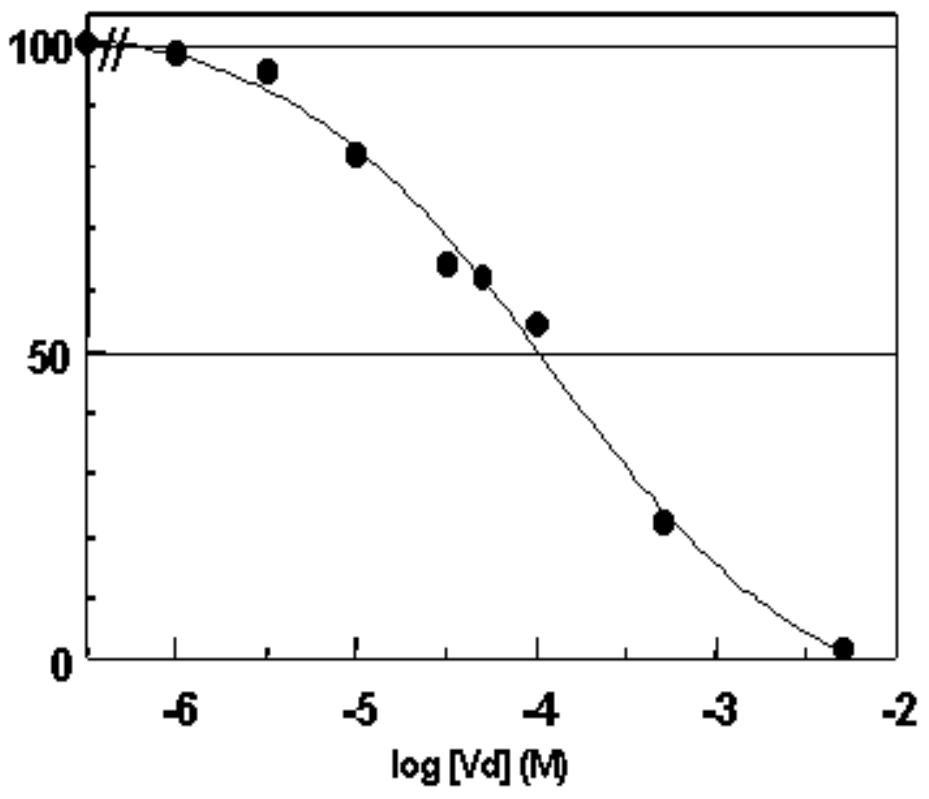

Fig. 5: Vanadate sensitivity of ATPase activity of the expressed Synechocystis 6xHis-ATPase. Plasma membrane vesicles from $E$. coli TKR2000/pQE32-8 (37.5 - 50 $\mu \mathrm{g}$ protein) were preincubated for 10 min in hydrolysis buffer plus 100 $\mu \mathrm{M} \mathrm{Ca}^{2+}$ at $37^{\circ} \mathrm{C}$, together with varying concentrations of vanadate, and rates of ATP hydrolysis were determined after addition of $\left[\gamma^{32} \mathrm{P}\right]$ ATP. Control activity was $3.61 \mu \mathrm{mol} / \mathrm{h} \times \mathrm{mg}$ of protein and inhibition is given in percentage of control rate. The data were fitted in a sigmoidal Boltzman curve; $50 \%$ inhibition was at $119 \mu \mathrm{M}$ vanadate.

The expressed ATPase is sensitive to vanadate - the inhibitor of all P-ATPases - with an $\mathrm{IC}_{50}$ of $119 \mu \mathrm{M}$ while total inhibition of the enzyme is obtained by $\mathrm{mM}$ concentrations (see Fig. 5). The apparent vanadate affinity is in the same range as found for $\operatorname{SER~} \mathrm{Ca}^{2+}$-ATPase isoforms $(10,8)$, but is much higher than $\mathrm{IC}_{50}$ values for PM Ca ${ }^{2+}$-ATPases (2-3 $\mu \mathrm{M}$, (19)). The $\mathrm{Ca}^{2+}$-ATPase from Synechoccocus 7942 seems to be more sensitive to vanadate; its calcium transport is totally blocked by $250 \mu \mathrm{M}$ vanadate (5).

To our knowledge with the Arabidopsis $\mathrm{H}^{+}$-ATPase isoform AHA2 expressed in yeast only one further example describing the expression of a His-tagged P-ATPase exists (22). Recently, the turgor sensor subunit kdpD of $E$. coli was expressed as His-tagged version (4). However, our results demonstrate that E. coli can be used as host for the expression of a functional P-ATPase if several precautions regarding its toxicity are undertaken. Further, the here described method might also be useful for achieving purification of other P-type ATPases. Compared to other expression systems like yeast, baculovirus or mammalian cell cultures, the $E$. coli host has many advantages in respect to its easy handling, short reproduction time, and low costs.

\section{ACKNOWLEDGEMENTS}

This work was supported by grants from the Deutsche Forschungsgemeinschaft. I would like to thank Jutta Richter for excellent technical assistance and Dr. Thomas Jahn (KVL University) for critically reading the manuscript. 


\section{REFERENCES}

1. Møller J.V., Juul B., le Maire M. 1996. Structural organization, ion transport, and energy transduction of P-type ATPases. Biochim. Biophys. Acta 1286, 1-51.

2. Tang X., Halleck M.S., Schlegel R.A., Williamson P. 1996. A subfamily of P-type ATPases with aminophospholipid transporting activity. Science 272, 1595-1497.

3. Geisler M., Koenen W., Richter J., Schumann J. 1998. Expression and characterization of a Synechocystis PCC 6803 P-type ATPase in E. coli plasma membranes. Biochim. Biophys. Acta 1368, 267-275.

4. Jung K., Tjaden B., Altendorf K. (1997) Purification, Reconstitution, and Characterization of kdpD, the Turgor Sensor of Escherichia coli. J. Biol. Chem. 272, 10847-10852.

5. Berkelman T., Garret-Engele P., Hoffman N.E.1994. The pacL gene of Synechococcus sp. Strain PCC 7942 encodes a Ca ${ }^{2+}$-Transporting ATPase. J. Bacteriol. 176, 4430-4436.

6. Lichtner R., Wolf H.U. 1980. Phosphorylation of the isolated high-affinity $\left(\mathrm{Ca}^{2+}+\mathrm{Mg}^{2+}\right)$ ATPase of the human erythrocyte membrane. Biochim Biophys Acta 598, 472-85.

7. Hsieh W., Pierce W.S., Sze H. 1991. Calcium-pumping ATPases in vesicles from carrot cells. Stimulation by calmodulin or phosphatidylserine, and formation of a 120 kilodalton phosphoenzyme. Plant Physiol 97, 1535-1544.

8. Okorokov L.A., Tanner W., Lehle L. 1993. A novel primary $\mathrm{Ca}^{2+}$-transport system from Saccharomyces cerevisiae. FEBS Lett 216, 573-577.

9. Bowman E.M., Siebers A., Altendorf K. 1988. Bafilomycins: A class of inhibitors of membrane ATPases from microorganisms, animal cells, and plant cells. Proc. Natl. Acad. Sci. USA 85, 79727976.

10. Lytton J., Westlin M., Burk S.E., Shull G.E., MacLennan D.H. 1992. Functional comparisons between isoforms of the sarcoplasmic or endoplasmic reticulum family of calcium pumps. J. Biol. Chem. 267, 14483-14489.

11. Hochuli E., Döbeli H., Schacher A. 1987. New metal chelate adsorbenss selective for proteins and peptide containg neighbouring histidine residues. J. Chromatography 411, 177-184.

12. Geisler M., Richter J., Schumann J. (1993) Molecular Cloning of a P-type ATPase Gene from the Cyanobacterium Synechocystis sp. PCC 6803. Homology to Eukaryotic $\mathrm{Ca}^{2+}$-ATPases. J. Mol. Biol 243, 1284-128913.

13. Kaneko T., Sato S., Kotani H., Tanaka A., Azamizu E., Nakamura Y., Miyajima N., Hirosawa M., Sugiura M., Sasamoto S., Kimura T., Hosouchi T., Matsuno A., Muraki A., Nakazaki N., Naruo K., Okumura S., Shimpo S., Takeuchi C., Wada T., Watanabe A., Yamada M., Yasuda M., Tabata S. 1996. Sequence analysis of the genome of the unicellular cyanobacterium Synechocystis sp. strain PCC6803. II. Sequence determination of the entire genome and assignment of potential protein-coding regions. DNA Res. 3, 109-13614.

14. Siebers A., Altendorf K. 1988. The $\mathrm{K}^{+}$-translocating Kdp-ATPase from Escherichia coli. Eur. J. Biochem 178, 131-140.

15. Geisler M., Jakobs. B., Richter J., Schumann J. 1996. Expression and Characterization of a Synechocystis PCC 6803 P-type ATPase in E. coli Plasma Membranes. Biochim. Biophys. Acta 1309, 189-193. 
16. Clarke D.M., Loo T.W., MacLennan D.H. 1990. Functional Consequences of Mutations of Conserved Amino Acids in the $\beta$-Strand Domain of the $\mathrm{Ca}^{2+}$-ATPase of Sarcoplasmic Reticulum. $J$. Biol. Chem. 265, 14088-14092.

17. Inesi G., Zhang Z., Sagara Y., Kirtley M.E. 1994. Intracellular signaling through long-range linked functions in the $\mathrm{Ca}^{2+}$ transport ATPase. Biophys. Chemistry 50, 129-138.

18. Sarkadi B., Enyedi A., Földes-Papp Z., Gárdos G. 1986. Molecular Characterization of the in Situ Red Cell Membrane Calucium Pump by Limited Proteolysis. J. Biol. Chem. 261, 9552-9557.

19. Carafoli E. 1991. Calcium Pump of the Plasma Membrane. Phys. Rev. 71 129-153.

20. Carafoli E. 1995. Biogenesis: Plasma membrane calcium ATPase: 15 years of work on the purified enzyme. FASEB 8, 993-1002.

21. Heim R., Iwata T., Zvaritch E., Adamo H.P., Rutishauer B., Strehler E.E., Guerini D., Carafoli E. 1992. Expression, Purification, and Properties of the Plasma Membrane $\mathrm{Ca}^{2+}$ Pump and of Its Nterminally Truncated 105-kDa Fragment. J. Biol. Chem. 267, 24476-24484.

22. Lanfermeijer F.C., Venema K., Palmgren M.G. 1997. Purification of heterologous expressed plant plasma membrane $\mathrm{H}^{+}$-ATPase by $\mathrm{Ni}^{2+}$ affinity chromatography. Ann. NY Acad. Sci. 834, 139-141.

23. Papp B., Enyedi A., Kovács T., Sarkadi B., Wuytack F., Thastrup O., Gárdos G., Bredoux R., Levy-Toledano S., Enouf J. 1991. Demonstration of Two Forms of Calcium Pumps by Thapsigargin Inhibition and Radioimmunoblotting in Platelet Membrane Vesicles. J. Biol. Chem. 266, 14593-14596.

24. Laemmli U.K. 1970. Cleavage of structural proteins during assembly of the head of bacteriophage T4. Nature 227, 680-685.

25. Villalba J.M., Palmgren M.G., Berberián G.E., Ferguson C., Serrano R. 1992. Functional Expression of Plant Plasma Membrane $\mathrm{H}^{+}$-ATPase in Yeast Endoplamic Reticulum. J. Biol. Chem. 267, 12341-12349.

26. Miroux B, Walker J.E. 1996. Over-production of proteins in Escherichia coli: mutant hosts that allow synthesis of some membrane proteins and globular proteins at high levels. J. Mol. Biol. 260, 289-298. 